\title{
РОЗРАХУНОК ДОЦЛЬНОГО ОБСЯГУ АВТОМАТИЧНОГО ЧАСТОТНОГО РОЗВАНТАЖЕННЯ І ЙОГО РОЗМІЩЕННЯ В ЕНЕРГОСИСТЕМІ 3 РОЗПОДІЛЕНИМИ ДЖЕРЕЛАМИ ЕЛЕКТРИЧНОЇ ЕНЕРГІЇ
}

\author{
В.А. Литвинчук ${ }^{1}$, наук. співроб., М.І. Каплін ${ }^{2}$, канд. техн. наук, О.О. Кармазін ${ }^{1}$, канд. техн. наук \\ ${ }^{1}$ Інститут відновлюваної енергетики НАН України, \\ 02094, вул. Гната Хоткевича, 20А, м. Київ, Україна. \\ ${ }^{2}$ Інститут загальної енергетики НАН України, \\ 03150, вул. Антоновича, 172, м. Київ, Україна.
}

Система автоматичного частотного розвантаження (АЧР) є одним із основних засобів, який иироко застосовується в енергосистемах для стримування ивидкого падіння частоти. Система АЧР здатна за мілісекунди відключити частину споживачів, а за секунди - зупинити падіння частоти в районах енергосистеми, які утворилися в результаті каскадної аварії з відключення ліній $і$ генераторів. Для підтримки тимчасового балансу активної потужності в аварійних ситуаціях в енергосистемі повинна бути передбачена кількість навантаження на відключення.

Тому національні оператори систем передачі або мережа операторів систем передачі електроенергї встановлюють так званий загальний обсяг розвантаження. Найчастіше в стандартах та нормативних документах енергосистем ией показник розраховують для загального пікового попиту $і$ рекомендують розмістити в енергосистемі рівномірним географічним способом. Такий спосіб розмішення загального обсягу розвантаження не враховує структуру електромережі, добової та сезонної зміни потужностей генерачії і споживання, незважаючи на те, щзо стандарти, нормативні документи вимагають ие враховувати. В роботі запропоновано математичну модель і спосіб визначення загального обсягу розвантаження системи АЧР $і$ його розміщення в мережі енергосистеми з урахуванням розподілених (у вузлах споживачів) відновлюваних джерел енергії, ймовірних варіантів аварійного поділу енергосистеми, вимог міжнародних стандартів та нормативних документів, що регулюють функиіонування систем протиаварійного захисту в галузі електроенергетики. Модель являє собою задачу иілочисельного (бінарного) лінійного програмування, щзо здійснює вибір оптимального за критерієм категорійності набору пристроїв АЧР, які розміщені у наперед заданих вузлах енергосистеми і спрацювання яких забезпечує баланс потужності в аварійних районах ї̈ поділу. Електричні параметри усталених режимів, а також ефективність оптимального обсягу $і$ розподілу розвантаження в мережі визначаються $і$ перевіряються (верифікуються) у серії апріорних та апостеріорних розрахунків на точних математичних моделях, визнаних у світовій практиці програмних продуктів електроенергетики. Отриманий таким чином розподіл обсягів розвантаження підвищує імовірність балансування якнайбільшої кількості аварійних районів енергосистеми за умови задоволення вимог щуодо частотно-часової зони відповідних перехідних процесів. Бібл. 9, табл. 3, рис. 2.

Ключові слова: автоматичне частотне розвантаження, відновлювані джерела енергї, джерела розподіленої генерачї, обсяг розвантаження, розміщуення пристроїв системи АЧР.

\section{COMPUTATION OF AN EXPEDIENT AMOUNT OF DEMAND THE UNDER FREQUENCY LOAD SHEDDING AND ITS PLACEMENT IN THE POWER SYSTEM WITH DISTRIBUTED SOURCES OF ELECTRICAL ENERGY}

\author{
V. Lytvynchuk ${ }^{1}$, research associate, M. Kaplin ${ }^{2}$, candidate of technical sciences, O. Karmazin ${ }^{1}$, candidate of technical sciences \\ ${ }^{1}$ Institute of Renewable Energy of the National Academy of Sciences of Ukraine, \\ 02094, 20A Hnata Khotkevycha St., Kyiv, Ukraine. \\ ${ }^{2}$ Institute of General Energy of the National Academy of Sciences of Ukraine, \\ 03150, 172 Antonovycha St., Kyiv, Ukraine.
}

Under Frequency Load Shedding (UFLS) is one of the main tools widely used in power systems to prevent frequency dropping too much. The UFLS is able to disconnect some consumers in milliseconds, and in seconds to stop the frequency drop in areas of the power system, which were formed as a result of a cascade accident to disconnect lines and generators. 
To support a temporary balance of active power in emergency in power system must be provided an amount of Demand for disconnection. Therefore, the National Transmission System Operators (TSO) or the Network of Transmission System Operators for Electricity establish the so-called Total Load Shed (TLS). Most often in the standards and policy of power systems, this indicator is calculated for total peak demand and recommended to place in the power system evenly geographically. This mode of placing TLS does not take into account the structure of power system, daily and seasonal changes in generation capacity and consumption, despite the fact that standards and policy the TSO require it to be taken into account. A mathematical model and a method are propposed determining total load shedding (TLS) the Under Frequency Load Shedding (UFLS) Power System and its placement. TLS is determined taking into account distributed (at consumer nodes) renewable energy sources, possible options for emergency separation of the power system, requirements of international standards and policy the functioning of Power Systems. The model is an integer (binary) linear programming problem. Ooptimal relays are selected for UFLS based on the categorization criterion located in predetermined nodes of the Power System whose operation ensures the power balance in emergency separation areas. The electrical parameters of the normal modes, as well as the efficiency of the optimal amout of Demand load shedding and distribution its in the network are determined and verified (detected) in a series of a priori and a posteriori calculations on exact mathematical models of the software products of the electric power industry recognized in the world practice. The distribution of the amout of Demand load shedding in case of an emergency situation increases the likelihood of balancing a larger number of emergency areas of the power system. Ref. 9, tabl. 3, fig. 2.

Keywords: under frequency load shedding, renewable energy sources, distributed generation sources, placement of relays UFLS.

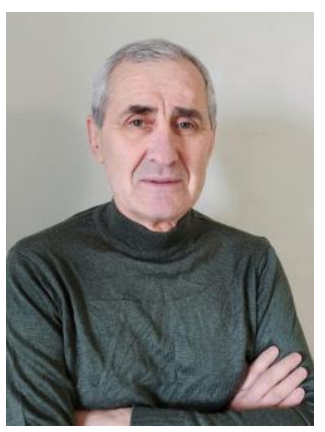

В.А. Литвинчук V. Lytvynchuk

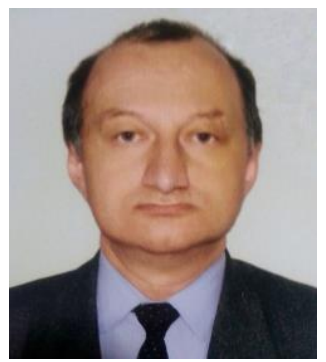

M.I. Каплін M. Kaplin
Відомості про автора: науковий співробітник відділу комплексних енергосистем Інституту відновлюваної енергетики НАН України

Освіта: Київський політехнічний інститут. Спеціальність «Електричні станції»

Наукова сфера: математичне моделювання енергосистем та розподільних мереж, аварійні режими роботи

Публікації: 18

ORCID: $0000-0003-4727-7800$

Контакти: +38(044)206-28-09

e-mail: volyt@ukr.net

Відомості про автора: провідний науковий співробітник відділу оптимізації розвитку паливних баз Інституту загальної енергетики НАН України

Освіта: Київський державний університет ім. Т.Г. Шевченка, фізичний факультет. Спеціальність «Фізик. Теоретична фізика. Викладач»

Наукова сфера: економіко-математичне моделювання систем енергетики, методи оптимізації, паливно-енергетичні баланси Публікації: 56

ORCID: 0000-0001-9328-4257

Контакти: +38(044)294-67-26

e-mail: nicko.droppero@ukr.net
Author information: Research Associate of the Institute of Renewable Energy of the NAS of Ukraine

Education: Kyiv Polytechnic Institute, specialty power plants

Research area: mathematical modeling of power systems and distribution networks, emergency modes of operation

Publications: 18

ORCID: 0000-0003-4727-7800

Contacts: +38(044)206-28-09

e-mail: volyt@ukr.net

Author information: Leading research fellow, Department of fuel bases development optimization, Institute of General Energy, National Academy of Sciences of Ukraine Education: Taras Shevchenko Kyiv State University, Faculty of Physics, «Physicist. Theoretical physics. Teacher»

Research area: economic and mathematical models in power system simulation, optimization methods, fuel and energy balances Publications: 56

ORCID: 0000-0001-9328-4257

Contacts: +38(044)294-67-26

e-mail: nicko.droppero@ukr.net 


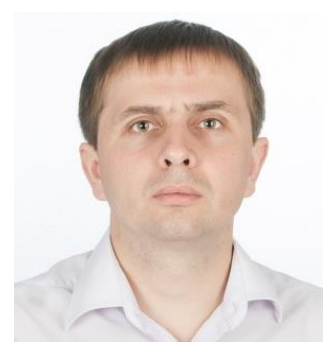

O.О. Кармазін

O. Karmazin
Відомості про автора: старший науковий співробітник відділу комплексних енергосистем Інституту відновлюваної енергетики НАН України

Освіта: Національний технічний університет «Харківський політехнічний інститут», фізико-технічний факультет. Спеціальність «Нетрадиційні джерела енергії»

Наукова сфера: функціонування і паралельна робота різнотипних відновлюваних джерел енергії в електромережі

Публікації: 29

ORCID: 0000-0002-7628-6880

Контакти: +38 (044) 206-28-09

e-mail: alexey.karmazin@gmail.com
Author information: senior researcher of

Department of Complex Power Systems of the Institute of Renewable Energy of the National Academy of Sciences of Ukraine

Education: National Technical University

Kharkiv Polytechnic Institute, Physical-

Technical Faculty, «Non-Conventional Sources of Energy»

Research area: operation and parallel operation of various types of renewable energy sources in the grid

Publications: 29

ORCID: 0000-0002-7628-6880

Contacts: +38 (044) 206-28-09

e-mail: alexey.karmazin@gmail.com
Перелік використаних позначень та скорочень:

АЧР - автоматичне частотне розвантаження;

ЗОР - загальний обсяг розвантаження;

Вступ. Всі масштабні аварії електроенергетичних систем, які супроводжувалися глибоким зниженням частоти, протягом останніх десятиліть мали каскадний характер [1-3]. Каскадне відключення ліній електропередавання (ЛЕП) призводило до поділу схеми на електрично не пов'язані райони, які не були вчасно збалансовані засобами протиаварійної автоматики. $\mathrm{B}$ результаті ці райони були затемнені $[3,4]$.

Разом 3 тим повних затемнень, які охоплюють всю електричну мережу і призводять до знеструмлення всіх споживачів, протягом останніх десятиліть у світовій електроенергетиці не спостерігалося. Це можна пояснити тим, що сучасні енергосистеми мають настільки велику загальну потужність агрегатів, що відмова одного 3 них здійснює відносно незначний вплив на іï роботу й не викликає великих змін електричних режимів чи будь-яких негативних наслідків. Можна стверджувати, що зниження частоти до рівня перших уставок автоматичного частотного розвантаження (АЧР) в енергосистемі, яка не була аварійно поділена, $\epsilon$ малоімовірним. Сучасна енергосистема залишається стійкою до того часу, поки не починається ऑiі каскадний поділ.

Натомість в ізольованих районах, які утворилися внаслідок розвитку аварії і $€$
ОММ - оператор магістральних мереж;

САВН - спеціальна автоматика відмикання навантаження.

електрично відокремленими від енергосистеми, можуть виникати досить великі небаланси активної потужності. Це призводить до швидкого зниження або підвищення частоти. Якщо протиаварійна автоматика виявиться неспроможною збалансувати схему своєчасно, в межах такого району може статися затемнення енергосистеми, що значно ускладнює процес іiі відновлення. 3 метою скорочення часу відновлення енергосистеми необхідно обов'язково забезпечити тимчасове балансування електрично відокремлених районів.

Аналіз масштабних аварій [1] дозволяє побачити характерну послідовність змін в енергосистемі, які супроводжуються швидким зниженням або підвищенням частоти:

1. Аварійне відключення електростанції, або блоку електростанції, або ЛЕП.

2. Перерозподіл дефіциту активної потужності між генераторами, що залишилися в роботі.

3. Зміна потокорозподілу потужності в ЛЕП.

4. Відключення ЛЕП внаслідок перевантаження або порушення стійкості.

5. Послідовне каскадне відключення ЛЕП.

6. Поділ схеми на незбалансовані райони район з надлишком генерувальної потужності і район $з$ дефіцитом такої потужності. 
В свою чергу аварійні явища у вже відокремлених районах мають певні характерні особливості, що залежать від їх надлишковості чи дефіцитності за потужністю.

I. Варіанти розвитку аварії в районі 3 надлишком генерувальної потужності:

\section{Варіант 1}

1. Підвищення частоти не більше ніж на 1,0 Гц.

2. Відхилення напруги у вузлах схеми в допустимих межах.

3. Ефективна робота автоматики регулювання частоти і напруги балансує район.

\section{Bapiaнm 2}

1. Підвищення частоти більше ніж на 1,0 Гц або миттєве підвищення напруги на шинах генераторів до мінімального рівня збудження.

2. Відключення генераторів.

3. Район 3 надлишком генерувальної потужності стає районом 3 дефіцитом генерувальної потужності.

4. Варіант розвитку аварії, як у районі 3 дефіцитом генерувальної потужності.

II.Варіанти розвитку аварії в районі 3 дефіцитом генерувальної потужності:

\section{Bapiaнm 1}

1. Швидке глибоке зниження частоти.

2. Ефективна робота системи АЧР балансує схему району.

\section{Варіант 2}

1. Швидке глибоке зниження частоти.

2. Система АЧР відмикає набагато більше потужності, ніж необхідно для балансування схеми.

3. Район 3 дефіцитом генерувальної потужності стає районом з її надлишком;
4. Варіант розвитку аварії, як у районі 3 надлишком генерувальної потужності.

\section{Варіант 3}

1. Швидке глибоке зниження частоти.

2. Система АЧР не може зупинити спадання частоти.

3. Затемнення району.

Як видно 3 наведених варіантів перебігу аварій, існує ймовірність того, що райони, які на початку аварійного перехідного процесу були надлишковими, під час його подальшого розвитку можуть стати дефіцитними, i, навпаки, попередньо дефіцитні райони можуть перетворитися в надлишкові. Крім того, в системі можуть виникати послідовні процеси наступного поділу вже виділених районів на менші за обсягом частини.

Тому для забезпечення можливості балансування якнайбільшої кількості районів в енергосистемі у разі виникнення аварій зі зміною частоти необхідно враховувати весь обсяг оперативного резерву в кожному з виділених районів, незважаючи на їх дефіцитність чи надлишковість на початку перехідного процесу.

Оперативний резерв енергосистеми має досить широкий часовий діапазон. Але в межах задачі розподілу резерву обсягу автоматичного частотного розвантаження доцільно розглянути можливості тільки тієї його частини, яка діє спільно 3 системою АЧР. Тому в табл. 1 представлено тільки той оперативний резерв енергосистеми, який можна ввести в дію в межах допустимої аварійної частотно-часової зони, а саме від 0 до 60 секунд. 
Табл. 1. Резерви підтримки частоти енергосистеми, які працюють в межах програми АЧР

Table 1. Frequency reserve of the power system, which operates within Performance Characteristic of UFLS Program

\begin{tabular}{|c|c|c|}
\hline & Назва резерву & $\begin{array}{l}\text { Час введення в } \\
\text { дію }\end{array}$ \\
\hline \multirow{2}{*}{ 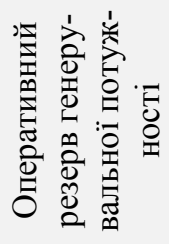 } & $\begin{array}{c}\text { Обертовий резерв активної потужності, який розміщений на агре- } \\
\text { гатах електростанцій }\end{array}$ & $15-30 \mathrm{c}$ \\
\hline & $\begin{array}{c}\text { Високоманеврова генерація, що розміщується на агрегатах, час } \\
\text { пуску яких не перевищує час введення обертового резерву }\end{array}$ & $20-30 \mathrm{c}$ \\
\hline \multirow{5}{*}{ 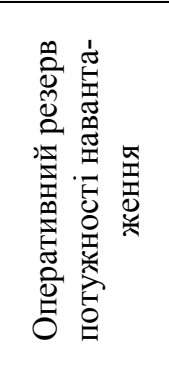 } & Споживачі, що забезпечують регулювальний ефект навантаження & Миттево \\
\hline & $\begin{array}{c}\text { Споживачі, що підключені до спеціальної автоматики відключен- } \\
\text { ня навантаження }\end{array}$ & Менше 1 c \\
\hline & $\begin{array}{c}\text { Споживачі, що підключені до пуску за швидкістю зниження } \\
\text { частоти (Rate of Change of Frequency (RoCoF) }\end{array}$ & Менше 1 с \\
\hline & $\begin{array}{c}\text { Споживачі, що підключені до системи автоматичного частотного } \\
\text { розвантаження без витримки часу (АЧР-1) }\end{array}$ & Менше 1 c \\
\hline & $\begin{array}{c}\text { Споживачі, що підключені до системи автоматичного частотного } \\
\text { розвантаження з витримкою часу (АЧР-2) }\end{array}$ & Більше 5 с \\
\hline
\end{tabular}

3 метою дослідження будь-якої аварії, пов'язаної зі змінами частоти, перехідний процес поділяють на два часові інтервали. В першому інтервалі досліджується можливість стримати падіння частоти, а в другому - можливість іiі відновлення до величини, близької до номінального значення. Перший інтервал перехідного процесу - від 0 до, орієнтовно, 510 секунд, а другий - від 10 до 60 секунд.

Першими стримують падіння частоти споживачі, які забезпечують регулювальний ефект навантаження (див. табл. 1). Цей ефект залежить від частки двигунів у навантаженні, а також від типу механізмів, які вони обертають. Відомо, що зменшення частоти на $1 \%$ зменшує навантаження на 1-3\%. Тому за умови досягнення нею рівня спрацювання перших уставок АЧР, потужність навантаження може зменшитись на 2-6\%. Обсяги цього резерву спрогнозувати неможливо, але його ефективність відчутна, коли виникає невеликий дефіцит активної потужності. Він утримує частоту на рівні вище верхньої уставки АЧР, фактично блокуючи відключення споживачів до моменту введення резерву генерувальних потужностей (див. табл. 1).

Далі, у вказаній нижче послідовності, починають діяти спеціальна автоматика відмикання навантаження (CABH) за фактом відмикання ЛЕП, або перетину, та АЧР-1Ш - швидкодійна категорія АЧР, що відмикає споживача за показником швидкості зниження частоти і АЧР-1 [8]. Зазвичай резерви під'єднаної потужності САВН і АЧР-1Ш суміщають 3 частиною резерву системи АЧР, яка діє за показником зміни частоти. Як виняток, ця автоматика може мати також свій індивідуальний резерв. Після спрацювання САВН, АЧР-1Ш i АЧР-1, залежно від набору уставок реле в районі, можуть мати місце два варіанти розвитку перехідного процесу. В першому випадку за рахунок цього резерву в районі буде призупинено падіння частоти i здійснено ii підвищення до номінального значення. В другому випадку може бути тільки призупинене падіння частоти. Функція іiі підвищення буде розподілена між резервами генерувальних потужностей i AЧР-2 або забезпечена тільки одним із цих резервів.

Від ефективності використання зазначених резервів буде залежати можливість утримання частоти в допустимій частотно-часовій зоні до моменту введення в дію резервів генерувальних потужностей і АЧР-2.

Резерви генерувальних потужностей i АЧР-2 в будь-якому випадку мають забезпечити підвищення частоти без порушення меж частотно-часової зони. Для цього в будь-якому виділеному районі необхідно мати резерв такої потужності. Недостатність резерву саме цієї 
потужності може викликати вторинне сповзання частоти і затемнення району.

Більшість енергосистем у світі не використовує АЧР-2, в тому числі країни, які $є$ членами ENTSO-E, i CША [5, 6]. У цих енергосистемах перевага надається споживачеві електроенергії, тобто мінімізується кількість відключень за рахунок введення достатнього резерву генерувальних потужностей. На думку авторів, це знижує надійність енергосистеми внаслідок того, що достатність резерву генерувальних потужностей для енергосистеми в цілому не завжди гарантує його достатність в кожному окремому районі й для будь-якого режиму енергопостачання.

Наразі АЧР-2 використовують тоді, коли 3 технічних причин не вистачає оперативного резерву генерувальної потужності для балансування енергосистеми.

Підсумовуючи вищенаведене, можна зробити висновок, що 3 усіх видів резервів потужності, представлених в табл. 1, зупинити швидке падіння частоти зі значним дефіцитом активної потужності може лише оперативний резерв споживачів, підключених до АЧР-1.

Тому АЧР-1 є єдиним засобом протиаварійної автоматики енергосистеми, який може стримати швидке глибоке сповзання частоти. Протягом декількох секунд АЧР-1 може відключити достатню частину споживачів і збалансувати дефіцитні райони енергосистеми, які утворилися в результаті каскадної аварії 3 відключення ЛЕП і генераторів.

\section{Постановка задачі.}

Відключення груп споживачів здійснюється системою АЧР послідовно і згідно 3 встановленим для них показником категорійності. Для успішного запобігання глибокому спаданню частоти ця система має бути забезпечена необхідним обсягом потужності розвантаження, щоб гарантувати тимчасовий баланс активної потужності в кожному виділеному районі енергосистеми.

3 цією метою національні системні оператори, або мережа системних операторів електроенергетики, задають показник так званого загального обсягу розвантаження (3ОР). До системи АЧР у різних енергосистемах світу під'єднують від 30 до 60 \% загальної потужності споживачів. Цей показник вводиться в стандарти енергосистеми узагальнено й в наказовій формі (директивно) нормативними документами. Через це не завжди зрозуміло, від якої потужності споживачів вираховується згаданий відсоток. Найчастіше $30 \mathrm{P}$ розраховують як відсоток від максимального навантаження енергосистеми. Такий підхід використовують і в об'єднаній енергосистемі України.

Визначений у такий спосіб обсяг розвантаження в переважній більшості випадків пропонується розміщувати в енергосистемі рівномірно й так званим географічним способом. Проте незважаючи на можливість «географічно розмістити» реле частоти на території країни, або енергосистеми, потужності під'єднаних до системи АЧР споживачів, у будь-якому разі необхідно враховувати їх значеннями у певних базових режимах електропостачання 3 відповідним обгрунтуванням вибору цих режимів саме для оцінки гранично допустимого обсягу розвантаження.

Зрозуміло, що вказані вище способи визначення 30Р i його розміщення в енергосистемі не враховують особливостей структури схеми їі електричних з'єднань, добової та сезонної зміни потужностей генерування i споживання, незважаючи на те, що стандарти енергосистеми, закріплені нормативними документами, вимагають це враховувати $[5,6,8]$. Також не враховується ймовірність поділу схеми на незбалансовані аварійні райони.

Тому, будуючи системи АЧР, до розвантаження залучають максимально можливу кількість споживачів. Зрозуміло, що залучена потужність, підключена до кожного окремого реле, змінюється протягом року. Отже, можна говорити про те, що й загальний обсяг розвантаження залежить від поточного режиму енергосистеми, але будь-яке його миттєве значення у відносних одиницях не може бути менше тієї величини, яка вказується у вимогах системного оператора або об'єднаної енергосистеми [5, 8]. Тому згадане вище значення 3ОР у відсотках можна розглядати лише як узагальнену потенційно досяжну межу для системи АЧР всієї енергосистеми. Це значення не $\epsilon$ інформативним щодо ефективності залученого обсягу потужності споживачів. Використання 3ОР як показника достатності розвантаження в загальному випадку не гарантує запобігання аварії, оскільки у разі поділу схеми й активації частотного розвантаження в аварійних 
режимах окремі райони можуть виявитися недостатньо забезпеченими необхідним обсягом розвантаження через особливості схеми електричної мережі і меж електрично відокремлених аварійних районів.

3 метою забезпечення достатності обсягу розвантаження у кожному аварійному районі в будь-який час активації АЧР необхідно визначити його значення 3 урахуванням структури та обсягів потужностей генерування i споживання, схеми електричних з'єднань електричної мережі, змінної потужності споживачів, підключених до реле частоти, параметрів базових режимів, зокрема тих, що мають місце під час максимального й мінімального навантаження енергосистеми.

У цьому дослідженні критерієм ефективності розподілу 3ОР вибрано мінімальний обсяг розвантаження, який необхідно мати в енергосистемі 3 урахуванням можливості іï поділу на, можна сказати, довільні електрично відокремлені аварійні райони.
При вирішені задачі мінімізації 3ОР необхідно використовувати модель енергосистеми для розрахунку пї усталених режимів. Математична модель дає змогу отримати сальдо перетоків через ЛЕП у місцях поділу схеми, а також значення дефіциту активної потужності у виділених районах. Для врахування змін навантаження, що утворює 3ОР, пропонується аналізувати три базові режими енергосистеми: максимального i мінімального навантаження, а також режим, у якому частка потужності, генерованої відновлювальними джерелами електроенергіі, є максимальною.

За допомогою схеми електричних з'єднань мережі енергосистеми вказуються межі виділених аварійних районів, а також, 3 використанням інформаційної моделі системи АЧР, визначаються множини пристроїв розвантаження і відповідний обсяг потужності підімкнених споживачів у цих районах. Набір даних системи АЧР формується у вигляді табл. 2 за результатами замірів у розподільній мережі для трьох вказаних вище базових режимів.

Таблиця 2. Фрагмент системи АЧР із налаштуваннями реле та потужностю відключення для кожного режиму

Table 2. Fragment UFLS Scheme with setting relays and amount of Demand load shedding for each mode

\begin{tabular}{|c|c|c|c|c|c|c|c|c|c|c|c|c|c|c|c|c|c|}
\hline \multirow{3}{*}{$\begin{array}{c}\text { Підстан- } \\
\text { ція }\end{array}$} & \multirow{3}{*}{$\begin{array}{c}\text { Приєд- } \\
\text { нання }\end{array}$} & \multirow{2}{*}{\multicolumn{2}{|c|}{ АЧР1 }} & \multicolumn{3}{|c|}{ Заміри } & \multirow{2}{*}{\multicolumn{2}{|c|}{ АЧР2-c }} & \multicolumn{3}{|c|}{ Заміри } & \multirow{2}{*}{\multicolumn{2}{|c|}{ АЧР2-H }} & \multicolumn{3}{|c|}{ Заміри } & \multirow{3}{*}{$\begin{array}{c}\text { Номер } \\
\text { вузла }\end{array}$} \\
\hline & & & & 1 & 2 & 3 & & & 1 & 2 & 3 & & & 1 & 2 & 3 & \\
\hline & & $\Gamma ц$ & сек & \multicolumn{3}{|c|}{$\mathrm{MBT}_{\mathrm{T}}$} & $\Gamma ц$ & Сек & \multicolumn{3}{|c|}{$\mathrm{MBT}_{\mathrm{T}}$} & Гц & сек & \multicolumn{3}{|c|}{$\mathrm{MB}$} & \\
\hline \multirow{10}{*}{$\begin{array}{c}\text { Підстанція } \\
110 \text { в }\end{array}$} & ТП-380 & 48,7 & 0,3 & 0,7 & 1 & 1,3 & 49 & 24 & 0,7 & 1,0 & 1,3 & & & 0 & 0 & 0 & 560 \\
\hline & ТП-379 & 48,7 & 0,3 & 0,1 & 0,1 & 0,1 & 49 & 24 & 0,1 & 0,1 & 0,1 & & & & & & \\
\hline & ТП-42 & 48,7 & 0,3 & & & 0,1 & 49 & 24 & & & 0,1 & & & & & & \\
\hline & ТП-209 & 48,7 & 0,3 & 0,3 & 0,6 & 0,8 & 49 & 24 & 0,3 & 0,6 & 0,8 & & & & & & \\
\hline & ТП-289 & 48,7 & 0,3 & & & & 49 & 24 & & & & & & & & & \\
\hline & 3ТП-324 & 48,7 & 0,3 & 0,1 & & & 49 & 24 & 0,1 & & & & & & & & \\
\hline & \begin{tabular}{|l|} 
ТП-370 \\
\end{tabular} & 48,7 & 0,3 & 0,1 & 0,2 & 0,2 & 49 & 24 & 0,1 & 0,2 & 0,2 & & & & & & \\
\hline & ТП-6 & 48,7 & 0,3 & 0,1 & 0,1 & 0,1 & 49 & 24 & 0,1 & 0,1 & 0,1 & & & & & & \\
\hline & ЗТП-324 & 48,7 & 0,3 & & & & 49 & 24 & & & & & & & & & \\
\hline & \begin{tabular}{|l|} 
ТП-379-2 \\
\end{tabular} & 48,7 & 0,3 & & & & 49 & 24 & & & & & & & & & \\
\hline
\end{tabular}

Отже, задача визначення ЗОР, а також його розміщення в розподільній електричній мережі має свої особливості для кожної досліджуваної енергосистеми, і для іiі ефективного вирішення необхідно здійснити певну послідовність кроків щодо розрахунку, підготовки й організації інформаційного забезпечення, моделювання балансу потужностей в енергосистемі, поділеній довільним чином на аварійні райони, і остаточної розрахункової розвантаження балансування пристроїв АЧР.

Доцільно відобразити цю послідовність у вигляді цілісного алгоритму визначення 3ОР, який наведено нижче й зображено на рис. 1 у вигляді блок-схеми. 
Блок 1 подає операцію виконання замірів потужності споживачів для трьох базових режимів енергосистеми - максимального i мінімального навантаження, а також режиму 3

максимальною часткою розподіленої генерації. Результати замірів, виконаних в розподільній мережі на цьому етапі заносяться до табл. 2, яка має таку структуру:

У стовпчику «Заміри»

1. Потужність на підстанціях і приєднаннях, коли енергосистема працює в режимі мінімального навантаження.
2. Потужність на підстанціях i приєднаннях, коли частка розподіленої генерації відновлювальних джерел електроенергії $\epsilon$ максимальною в структурі генерування.

3. Потужність на підстанціях i приєднаннях, коли енергосистема працює в режимі максимального навантаження.

$\mathrm{У}$ стовпчиках «АЧР1», «АЧР2-с», «АЧР2-н» містяться фактичні значення частоти і часу спрацювання діючих уставок системи АЧР, а в стовпчику «Номер вузла» - номер вузла розрахункової (заступної) схеми енергосистеми, до якого через ЛЕП під’єднана підстанція.

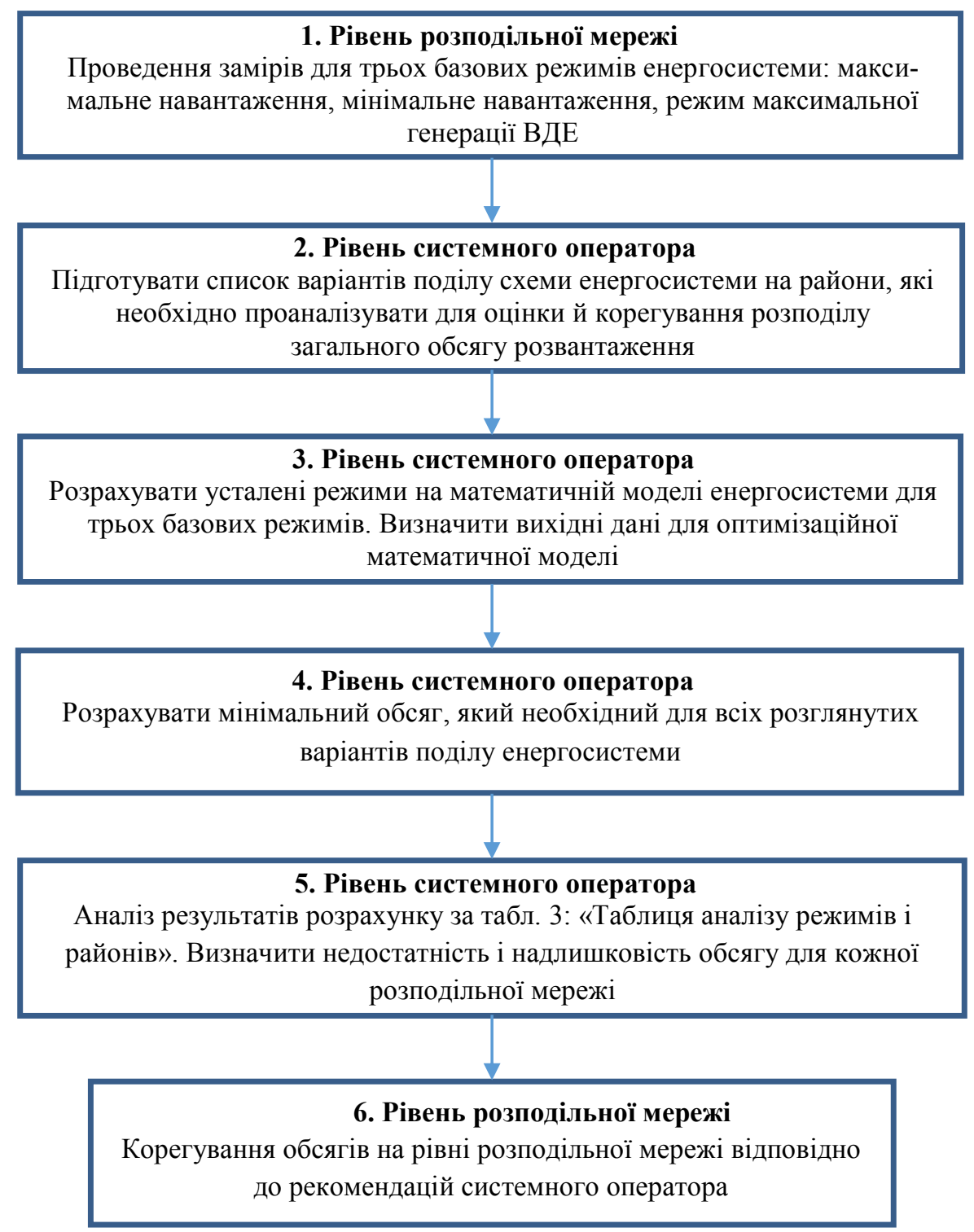

Рис. 1. Блок-схема алгоритму визначення загального обсягу розвантаження енергосистеми

Fig. 1 The flowchart of the algorithm for determining the total amount of Demand UFLS for the power system 
Блок 2 відображає етап підготовки переліку (множини) варіантів поділу схеми енергосистеми на аварійні райони, які підлягають аналізу для визначення i корегування розподілу ЗОР. До цього переліку додаються варіанти поділу енергосистеми, кожен 3 яких вказується переліком (множиною) ліній заступної схеми, які можуть послідовно відключитись внаслідок виникнення каскадної аварії. Перш за все такими лініями можуть бути контрольовані перетини (див. рис. 2, січні IV-IV i V-V). Крім того, зважаючи на те, що передбачити, які саме лінії і в якій послідовності будуть відключені в процесі розвитку аварії, фактично неможливо [9], доцільно розглянути варіанти довільного, певною мірою, поділу, які подаються на рис. 2 січними 1-1, 2-2, 3-3, 4-4.
На етапі, позначеному блоком 3, схемою алгоритму передбачено визначення (отримання) вихідних даних для оптимізаційної математичної моделі балансу обсягів потужності в аварійних районах за умови активації всіх реле. Тут виконуються розрахунки згаданих вище трьох базових усталених режимів за допомогою стандартного програмного забезпечення розрахунку усталених режимів. Зокрема, у цих розрахунках за допомогою відомої математичної моделі балансу активної i реактивної потужностей енергосистеми отримуються відповідні потоки потужностей у лініях заступної схеми для режимів максимального й мінімального добових навантажень енергосистеми, а також режиму максимальної частки розподіленої генерації.

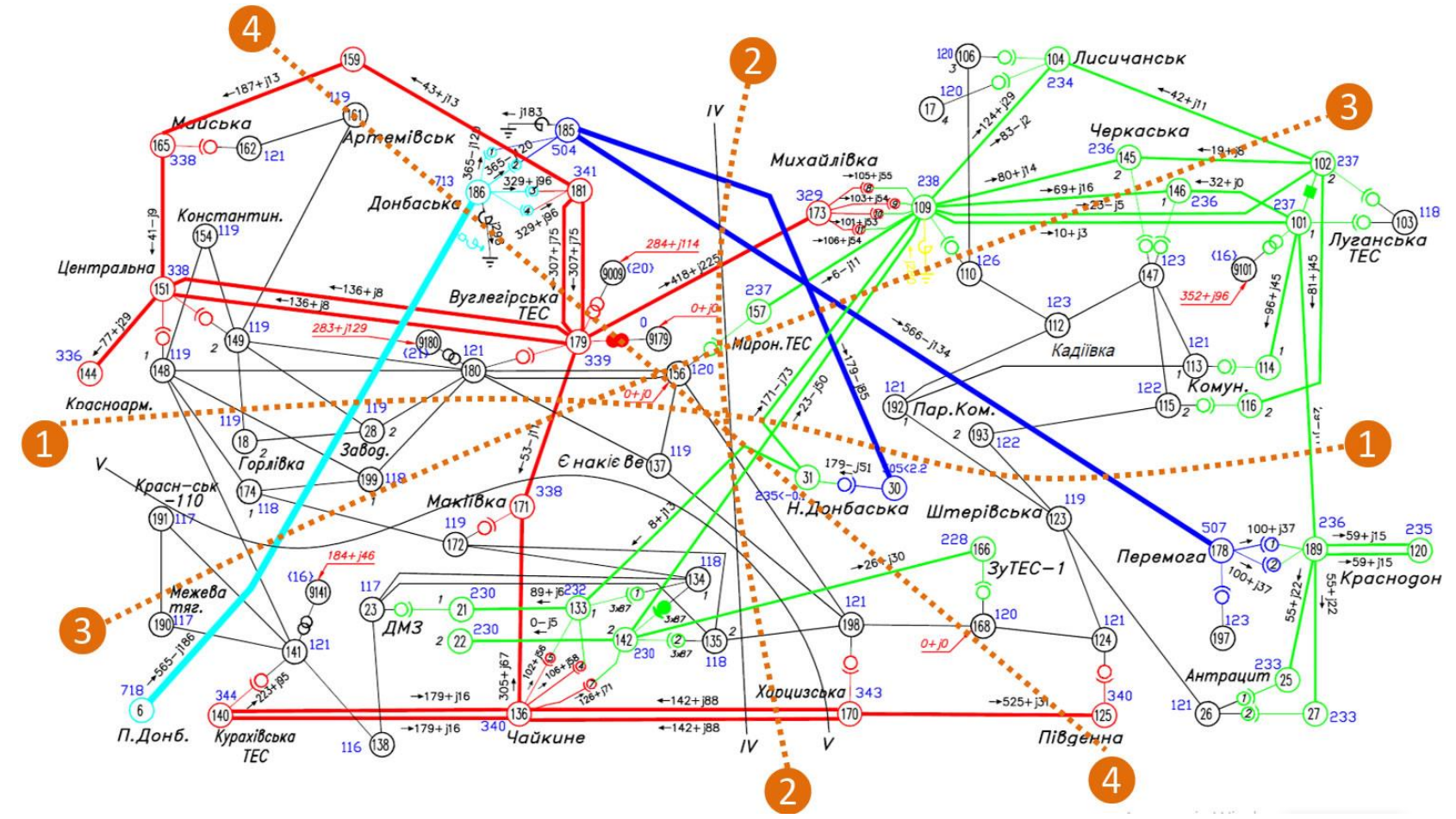

Рис. 2. Однолінійна схема моделі енергосистеми

Fig. 2. Single Line Diagram of Power System

На четвертому етапі алгоритму (блок 4) вирішується задача визначення ЗОР, тобто розраховується множина пристроїв АЧР (реле частоти) й відповідний обсяг під'єднаної до них потужності навантаження, необхідного для найбільш повного балансування всіх аварійних районів поділу енергосистеми у всіх варіантах поділу, які розглядалися на другому етапі алгоритму, позначеному на його схемі блоком 2.
3 цією метою використовується математична модель балансу потужностей в аварійно поділеній енергетичній системі, детальний виклад якої наведено нижче (1-3). Застосування моделі забезпечує здійснення аналізу та підвищення ефективності розміщення, а також визначення мінімального загального обсягу балансувальної потужності частотного розвантаження для всіх варіантів поділу 
енергосистеми. Фактично у такий спосіб отримується множина реле з відмінними від нуля цілочисельними (бінарними) інтенсивностями використання, які $є$ найбільш потрібними для розвантаження. Водночас можна стверджувати, що активація інших реле, які не збігаються 3 вибраними в оптимальному розв'язку задачі лінійного програмування цієї моделі, є досить малоімовірною у будь-якій аварійній ситуації. Як показує досвід використання алгоритму, така ймовірність залежить від вичерпності множини варіантів поділу енергосистеми, розробленої фахівцями диспетчерської служби на етапі 2 (блок 2). Отримані результати розрахунку доцільної для розвантаження множини реле частоти далі використовуються для побудови таблиці аналізу режимів і районів (табл. 3).

На п'ятому етапі алгоритму (блок 5) виконується аналіз результатів розрахунку за табл. 3, «Таблиця аналізу режимів і районів», зокрема визначається недостатність чи надлишковість обсягу розвантаження для кожної розподільної мережі.

Таблиця 3. Фрагмент таблиці аналізу режимів і районів

Table 3. Fragment of the table of analysis of modes and areas

\begin{tabular}{|c|c|c|c|c|c|c|c|c|}
\hline \multirow{2}{*}{$\begin{array}{c}\text { Номер } \\
\text { базового } \\
\text { режиму }\end{array}$} & \multirow{2}{*}{$\begin{array}{l}\text { Номер ава- } \\
\text { рійного } \\
\text { поділу енер- } \\
\text { госистеми }\end{array}$} & \multirow[t]{2}{*}{$\begin{array}{l}\text { Номер } \\
\text { району }\end{array}$} & \multicolumn{2}{|c|}{$\begin{array}{c}\text { Дефіцит } \\
\text { потужності } \\
\text { в районі }\end{array}$} & \multicolumn{2}{|c|}{$\begin{array}{c}\text { Запас обсягу } \\
\text { розвантаження } \\
\text { в районі }\end{array}$} & \multirow{2}{*}{$\begin{array}{c}\text { Сумарний об- } \\
\text { сяг розванта- } \\
\text { ження району } \\
\text { МВт }\end{array}$} & \multirow{2}{*}{$\begin{array}{c}\text { Обсяг розвантаження в } \\
\text { районі, який був задіяний } \\
\text { для всієї множини поділу } \\
\text { енергосистеми } \\
\text { МВт }\end{array}$} \\
\hline & & & $\mathrm{MBT}$ & $\%$ & $\mathrm{MBT}$ & $\%$ & & \\
\hline 1 & 2 & 1 & 842 & 15,5 & 133 & 24 & 2176 & 2034 \\
\hline 1 & 3 & 1 & 275 & 7,6 & 1423 & 39 & 1697 & 1551 \\
\hline 2 & 1 & 1 & 594 & 11.2 & 1758 & 33 & 2209 & 2352 \\
\hline
\end{tabular}

Кожен аварійний район у різних режимах має певний резерв потужності розвантаження. Разом 3 тим частина цього резерву може використовуватися в іншому районі, якщо деякі вузли його схеми належать до межі поділу енергосистеми, i, таким чином, мають електричне з'єднання з вузлами іншого району. В такому разі досягається можливість використання потужності розвантаження одного пристрою АЧР для балансування двох або більше аварійних районів, що значною мірою оптимізує використання ЗОР у бік його скорочення. Тому таблиця аналізу режимів і районів будується так, щоб надати можливість аналізу участі підмножин реле, які задіяні в конкретному режимі і районі, у розвантаженні, можливо, частковому, інших районів. Це дає змогу корегувати обсяги розвантаження в окремому районі й режимі 3 урахуванням загальносистемних потреб і можливостей окремої розподільної мережі.

Операцію остаточного корегування обсягів на рівні оператора розподільної мережі відповідно до рекомендацій оператора магістральних мереж (ОММ) відображено у блоці 6. Тут необхідно зазначити, що лише на рівні розподільної мережі наявні всі необхідні дані, на основі яких можна приймати рішення щодо підключення споживача до системи розвантаження. Тому зміну загальносистемного обсягу розвантаження ОММ здійснює опосередковано через оператора розподільної мережі. Разом 3 тим у світовій електроенергетиці існують різні умови підключення споживачів до системи розвантаження. У деяких державах таке підключення $\epsilon$ видом послуг, які належать до системних, а в інших - воно прирівнюється до системних послуг через використання гнучких тарифів за споживання електроенергії. Більше платить за електроенергію той споживач, який має найнижчу уставку за частотою або взагалі не бере участь у розвантаженні.

\section{Математична модель балансу} потужностей в аварійно поділеній енергетичній системі. Згідно 3 описаним вище алгоритмом задачі мінімально необхідний обсяг потужності розвантаження 


$$
P_{\tau, \min }^{L S}=\sum_{i=1}^{N_{U}} P_{i \tau} \cdot x_{i}^{o p t},
$$

де $\left\{x_{i}^{\text {opt }}\right\}, i=\overline{1, \ldots, N_{U}}-$ множина оптимальних значень бінарних змінних стану використання або невикористання пристрою $i$ для усунення наслідків довільної аварійної ситуації, що супроводжується зниженням частоти в електроенергетичній системі 3 наперед заданою множиною електричних режимів 3 виміряними потужностями на пристроях розвантаження, яка визначає мережевий розподіл використаної потужності розвантаження i знаходиться як розв'язок задачі цілочисельної оптимізації, яка полягає в наданні мінімального значення функції

$$
\sum_{i=1}^{N_{U}}\left(1-k_{i}\right) \cdot x_{i} \rightarrow \min
$$

за умов

$$
\begin{aligned}
& \sum_{i=1}^{N_{U}} A_{r i} \cdot\left(P_{i \tau}-G_{i \tau}^{R E S}\right) \cdot x_{i} \geq\left.\left. D_{r \tau}\right|_{r=\overline{1, N_{R^{-}}}}\right|_{\tau=\overline{1, N_{T}}}, \\
& \sum_{i=1}^{N_{U}} A_{r i} \cdot\left(P_{i \tau}-G_{i \tau}^{R E S}\right) \cdot x_{i} \geq\left.\left. s \cdot P_{r \tau}^{c o n s}\right|_{r=\overline{1, N_{R^{+}}}}\right|_{\tau=\overline{1, N_{T}}},
\end{aligned}
$$

де $A_{r i}$ - елемент матриці належності пристроїв розвантаження (реле частоти) до виділених районів: $A_{r i}=1$, якщо пристрій $i$ належить до виділеного району $r$ i $A_{r i}=0$ у протилежному випадку; $P_{i \tau} \quad-$ величина потужності навантаження, підключеного до пристрою $i$, виміряна у режимі $\tau ; G_{i \tau}^{R E S}-$ установлена активна потужність відновлюваних джерел електричної енергії, точки забезпечення потужності яких підпадають під дію пристрою $i$ у режимі $\tau ; D_{r \tau}$ - дефіцит активної потужності району $r$ у режимі $\tau$, отриманий як результат поділу схеми енергосистеми внаслідок аварій, що супроводжуються зниженням частоти; $s-$ відсоток обсягу навантаження, який установлюється системним оператором для залучення споживачів до розвантаження енергосистеми; $P_{r \tau}^{\text {cons }}-$ загальна активна потужність навантаження надлишкового району $r$ у режимі $\tau ; k_{i}-$ коефіцієнт категорійності споживача / діюча уставка за частотою, підключеного до пристрою $i ; x_{i}$ - шукана бінарна змінна стану пристрою $i: x_{i}=1$, якщо пристрій $i$ бере участь в розвантаженні енергосистеми; $N_{U}-$ кількість пристроїв розвантаження (реле) в енергосистемі; $N_{R^{-}}-$кількість виділених дефіцитних за активною потужністю районів енергосистеми; $N_{R^{+}}-$кількість виділених надлишкових за активною потужністю районів енергосистеми; $N_{T}-$ кількість вимірювань (замірів) на пристроях протягом розрахункового періоду $T$.

Результати досліджень. Розрахункову схему електроенергетичної системи наведено на рис. 2. Вона містить два контрольовані перетини IV-IV i V-V, внаслідок відімкнення яких утворилися відповідні аварійні райони (див. рис. 2). Крім того, розглядалися інші, досить відмінні один від одного варіанти поділу системи, щоби продемонструвати різноманітні випадки утворення довільних аварійних районів. Це варіанти поділу схеми, які потрапили у розрізи 1-1, 2-2, 3-3, 4-4. В результаті вирішення задачі, відповідно до описаного вище алгоритму, отримано «Таблицю аналізу режимів і районів» (див. опис 4-го і 5-го етапів алгоритму визначення 3ОР), фрагмент якої представлено в табл. 3.

Якби для розглядуваної електроенергетичної системи було необхідно виконати вимоги документа ENTSO-E [5] щодо 3ОР, то в цій системі до АЧР мало б бути підімкнено не менше $45 \%$ навантаження 3 відхиленням $+/-7 \%$. Це значить, що мінімальний 3ОР у відсотках має становити $38 \%$, а максимальний $-52 \%$.

Натомість 3 табл. 3 бачимо, що в першому і третьому рядках після покриття (задоволення) 
дефіцитів у запасі залишилось відповідно 24 (1334 МВт) $\quad$ і $33 \%$ (1758 МВт), що менше мінімально необхідного обсягу - $38 \%$. У другому рядку величина запасу становить $39 \%$ (1423 МВт), тобто є більшою за мінімально необхідний обсяг. Маючи ці значення запасів, можна розрахувати обсяг потужності споживачів, у мегаватах, який необхідно залучити до розвантаження у кожному виділеному районі, a отже, i 3ОР електроенергетичної системи в цілому.

Висновки. 1. Виконаний в роботі аналіз перебігу масштабних аварій зі зниженням частоти, а також властивостей різних типів оперативного резерву в електроенергетичних системах дозволив стверджувати, що система автоматичного частотного розвантаження наразі $\epsilon$ єдиним засобом балансування енергосистеми за умов виникнення значних за обсягом і раптових небалансів активної потужності, незважаючи на причини їх утворення. Необхідною умовою ефективного функціонування системи автоматичного частотного розвантаження $\epsilon$ достатність обсягів та доцільне розміщення потужності споживачів, підімкнених до цієї системи. Визначення достатнього обсягу розвантаження має здійснюватися лише на основі спільного аналізу особливостей структури мережі енергосистеми, а також потокорозподілу достатньої сукупності електричних режимів, що дозволяє отримати точні значення дефіцитів потужностей, а також доцільних джерел їх задоволення в множині засобів наявного оперативного резерву.

2. В роботі запропоновано спосіб та алгоритм визначення, а також математичну модель оптимального балансування доцільного обсягу оперативного резерву системи АЧР 3 урахуванням можливості поділу електроенергетичної системи на довільні електрично відокремлені аварійні райони. Застосування цих засобів оцінки і корегування обсягів розвантаження істотно зменшує ймовірність повного затемнення аварійних районів внаслідок виникнення складних каскадних аварій, що супроводжуються значним зниженням частоти. Створення послідовного алгоритму, що складається 3 формальних процедур вирішення задачі, запропоновані специфічні структури даних $\mathrm{i}$ математична модель балансування аварійних районів разом надають фахівцям технологічних та диспетчерських служб електроенергетичної системи засіб точного моделювання і побудови системи АЧР.

3. На прикладі реальної електроенергетичної системи шляхом розрахункового аналізу за допомогою наведеного алгоритму доведено, що величина загального обсягу розвантаження, регламентована чинними стандартами та нормативними документами діючого наразі законодавства у галузі електроенергетики, $є$ недостатньо надійним показником, що визначає базові властивості систем АЧР. 3 метою визначення доцільного значення цього показника, та пов'язаного 3 ним розміщення потужностей розвантаження в електроенергетичній системі необхідно послуговуватися точними інструментами розрахунку режимних станів системи. Сукупність та спосіб застосування таких інструментів пропонується в цьому дослідженні.

1. Veloza O.P., Santamaria F. Analysis of major blackouts from 2003 to 2015:Classification of incidents and review of main causes. The Electricity Journal. 2016. № 29(7). Pp. 42-49.

2. Yan R., Masood N.A., Saha T.K., Bai F., Gu H. The anatomy of the 2016 South Australia blackout: a catastrophic event in a high renewable network. IEEE Transactions on Power Systems. Sept. 2018. Vol. 33. Issue 5. Pp. 5374-5388.

3. Newman D.E., Carreras B.A., Lynch V.E., Dobson Ia.D, Newman D.E. Exploring Complex Systems Aspects of Blackout Risk and Mitigation. IEEE Transactions on Reliability. March 2011. Vol. 60. Issue 1. Pp. 134-143.

4. Інформаційні та аналітичні матеріали. Державна інспекція з експлуатації електричних станцій і мереж. Київ. 2009. $528 \mathrm{c}$.

5. ENTSO-E. Continental Europe Operation Handbook Policy 5: Emergency Operations. [Електронний ресурс]. URL: www.entsoe.eu (дата звернення: 13.03.2021).

6. Technical background for the Low Frequency Demand Disconnection requirements. ENTSO-E. November 2014. [Електронний ресурс].

URL:https://eepublicdownloads.entsoe.eu/cleandocuments/Network\%20codes\%20documents/NC\%20ER/14121 
5 Technical background for LFDD.pdf (дата звернення: 13.03.2021).

7. Lu M., ZainalAbidin W.A.W., Masri T., Lee D.H.A., Chen $S$. Under-Frequency Load Shedding (UFLS) Schemes -A Survey. International Journal of Applied Engineering Research. Vol. 11. 2016. № 1. Pp. 456-472.

8. Правила застосування системної протиаварійної автоматики запобігання та ліквідації небезпечного зниження або підвищення частоти в енергосистемах. [Електронний pecypc]. URL: https://zakon.rada.gov.ua/laws/show/z117703\#Техt (дата звернення: 13.03.2021).

9. Литвинчук B.A. Передбачення аварій з дефіцитом активної потужності в енергосистемах. Енергетика та електрифікація. 2004. № 6. С. 29-31.

\section{REFERENCES}

1. Veloza O.P., Santamaria F. Analysis of major blackouts from 2003 to 2015:Classification of incidents and review of main causes. The Electricity Journal. 2016. No. 29(7). Pp. 42-49. [in English].

2. Yan R., Masood N.A., Saha T.K., Bai F., Gu H. The anatomy of the 2016 South Australia blackout: a catastrophic event in a high renewable network. IEEE Transactions on Power Systems. Sept. 2018. Vol. 33. Issue 5. Pp. 5374-5388. [in English].

3. Newman D.E., Carreras B.A., Lynch V.E., Dobson Ia.D, Newman D.E. Exploring Complex Systems Aspects of Blackout Risk and Mitigation. IEEE Transactions on Reliability. March 2011. Vol. 60. Issue 1. Pp. 134-143. [in English].
4. Informatsiini ta analitychni materialy. [Information and analytical materials]. Derzhavna inspektsiia $\mathrm{z}$ ekspluatatsii elektrychnykh stantsii i merezh. Kyiv. 2009. 528 p. [in Ukrainian].

5. ENTSO-E. Continental Europe Operation Handbook Policy 5: Emergency Operations. [Electronic resource]. URL: www.entsoe.eu (Applying date: 13.03.2021). [in English].

6. Technical background for the Low Frequency Demand Disconnection requirements. ENTSO-E. November 2014. [Electronic resource].

URL: https://eepublicdownloads.entsoe.eu/cleandocuments/Network\%20codes\%20documents/NC\%20ER/14121 5_Technical_background_for_LFDD.pdf (Applying date: 13.03.2021). [in English].

7. Lu M., ZainalAbidin W.A.W., Masri T., Lee D.H.A., Chen $S$. Under-Frequency Load Shedding (UFLS) Schemes -A Survey. International Journal of Applied Engineering Research. Vol. 11. 2016. № 1. Pp. 456-472. [in English].

8. Pravyla zastosuvannia systemnoi protyavariinoi avtomatyky zapobihannia ta likvidatsii nebezpechnoho znyzhennia abo pidvyshchennia chastoty $\mathrm{v}$ enerhosystemakh. [Rules for the application of system emergency automation to prevent and eliminate dangerous reduction or increase of frequency in power systems]. [Electronic resource].

URL: https://zakon.rada.gov.ua/laws/show/z1177-03\#Text (Applying date: 13.03.2021). [in Ukrainian].

9. Lytvynchuk V.A. Peredbachennia avarii $\mathrm{z}$ defitsytom aktyv-noi potuzhnosti $\mathrm{v}$ enerhosystemakh. [Anticipation of accidents with a deficit of active power in power systems]. Enerhetyka ta elekt-ryfikatsiia. 2004. No. 6. Pp. 29-31 [in Ukrainian]. 